\title{
Learning instead of fighting: the impact of rabbinic theory on Jewish identity
}

\author{
Gerhard Langer
}

Rabbinic Judaism was a reaction to the destruction of the Jerusalem temple and the disaster of the Bar-Kochba uprising in the $1^{\text {st }}$ and $2^{\text {nd }}$ century CE. The rabbinic movement concentrated on the teaching and learning of the Torah, the uttering of God's will, which was intensively interpreted by the Rabbis. Not success in war, not political independence in a Jewish state, not political power or an imminent eschatological expectation should save and rescue Jewish identity, but the ambitious effort of learning and keeping the Torah up to date as a "wandering homeland". Often being a minority group, Judaism had to come to terms with majorities or other minorities finding a position of acculturation, openness and self-assurance. New approaches and solutions were based on old experiences and traditions and enriched with actual necessities and ideas, developing an intellectual Judaism in a diasporic context.

Gerhard Langer studied Catholic Theology, Jewish Studies and Old Semitic Philology in Salzburg and Vienna. He worked for many years at the University of Salzburg. Since 2010 he is Full Professor of Jewish Studies at the University of Vienna. His main scholarly interests focus on rabbinic Judaism and the impact of Jewish tradition on modern literature.

\section{Biblical fundamentalism?}

Would you think it was fundamentalism if you heard an older man with a beard instructing a group of other men with beards to kill three thousand men, because they made a picture of the invisible God?

Exod 32: ${ }^{25}$ Moses saw that the people were running wild and that Aaron had let them get out of control and so become a laughingstock to their enemies. ${ }^{26}$ So he stood at the entrance to the camp and said, Whoever is for the LORD, come to me. And all the Levites rallied to him. ${ }^{27}$ Then he said to them, This is what the LoRD, the God of Israel, says: Each man strap a sword to his side. Go back and forth through the camp from one end to the other, each killing his brother and friend and neighbor. ${ }^{28}$ The Levites did as Moses commanded, and that day about three thousand of the people died.

Would you think it is fundamentalism if a head of state orders the damage of all the remains of former or alternative religious utterances in his land? 
2 Kings $23:{ }^{4}$ The king ordered Hilkiah the high priest, the priests next in rank and the doorkeepers to remove from the temple of the LoRD all the articles made for Baal and Asherah and all the starry hosts. He burned them outside Jerusalem in the fields of the Kidron Valley and took the ashes to Bethel. ${ }^{5} \mathrm{He}$ did away with the idolatrous priests appointed by the kings of Judah to burn incense on the high places of the towns of Judah and on those around Jerusalem - those who burned incense to Baal, to the sun and moon, to the constellations and to all the starry hosts. ${ }^{6} \mathrm{He}$ took the Asherah pole from the temple of the LORD to the Kidron Valley outside Jerusalem and burned it there. He ground it to powder and scattered the dust over the graves of the common people. ${ }^{7} \mathrm{He}$ also tore down the quarters of the male shrine prostitutes that were in the temple of the LORD, the quarters where women did weaving for Asherah. ${ }^{8}$ Josiah brought all the priests from the towns of Judah and desecrated the high places, from Geba to Beersheba, where the priests had burned incense. He broke down the gateway at the entrance of the Gate of Joshua, the city governor, which was on the left of the city gate. ${ }^{9}$ Although the priests of the high places did not serve at the altar of the LORD in Jerusalem, they ate unleavened bread with their fellow priests. ${ }^{10}$ He desecrated Topheth, which was in the Valley of Ben Hinnom, so no one could use it to sacrifice his or her son or daughter in the fire to Molek. ${ }^{11} \mathrm{He}$ removed from the entrance to the temple of the LonD the horses that the kings of Judah had dedicated to the sun. They were in the court near the room of an official named Nathan-Melek. Josiah then burned the chariots dedicated to the sun. ${ }^{12} \mathrm{He}$ pulled down the altars the kings of Judah had erected on the roof near the upper room of Ahaz, and the altars Manasseh had built in the two courts of the temple of the LoRD. He removed them from there, smashed them to pieces and threw the rubble into the Kidron Valley. ${ }^{13}$ The king also desecrated the high places that were east of Jerusalem on the south of the Hill of Corruption - the ones Solomon king of Israel had built for Ashtoreth the vile goddess of the Sidonians, for Chemosh the vile god of Moab, and for Molek the detestable god of the people of Ammon. ${ }^{14}$ Josiah smashed the sacred stones and cut down the Asherah poles and covered the sites with human bones.

Would you think it is fundamentalism, when a priest kills a couple having intercourse, because the woman does not have the "right" religion, and the priest's act is actually supported by God?

Num 25: ${ }^{7}$ When Phinehas son of Eleazar, the son of Aaron, the priest, saw this, he left the assembly, took a spear in his hand ${ }^{8}$ and followed the Israelite into the tent. He drove the spear into both of them, right through the Israelite man and into the woman's stomach. Then the plague against the Israelites was stopped; ${ }^{9}$ but those who died in the plague numbered 24,000. ${ }^{10}$ The LoRD said to Moses, ${ }^{11}$ Phinehas son of Eleazar, the son of Aaron, the priest, has turned my anger away from the Israelites. Since he was as zealous for my honor among them as I am, I did not put an end to them in my zeal. ${ }^{12}$ Therefore tell him I am making my covenant of peace with him. ${ }^{13} \mathrm{He}$ and his descendants will have a covenant of a lasting priesthood, because he was zealous for the honor of his God and made atonement for the Israelites. 
These biblical proofs can be increased arbitrarily. They show the potential of the Jewish tradition, as well as any other monotheistic ${ }^{1}$ and, cautiously worded, every religious movement. There is no need at this point to demonstrate the many possible definitions of fundamentalism. It suffices to point out that the representatives of aforementioned acts had the right, given by a higher authority, to define what is right - and to implement it at all costs - or wrong, and to avoid, abolish or destroy it at all costs.

It is tempting to deliberate how Jewish civilization would have developed if Israel had endured as a sovereign national constant over the centuries. What would be if the temple had never been destroyed, if hundreds of priests could still follow their sacrificial rites, influential both in political and religious causes? What would be if a ruling dynasty after David reigned over a flourishing empire and could defend it or could even have expended it? Which writings would this civilization have produced?

This thought of Judaism in direct competition with Christianity and Islam is tempting indeed. A Judaism based on profane and spiritual power, implementing its cultural identity by use of political and military means. Which theology would have developed? Which image of God and men would have prevailed? Which kinds of religious practice would have become dominant?

In other words: religious perceptions never develop disconnected from living conditions and concrete historical political circumstances.

What does this mean for the view on Judaism?

The destruction of the Jerusalem temple, and more than that the total counterinsurgency of the Bar-Kochba revolt, destroyed dreams of national Jewish selfdefinition in Israel, and for a while it stopped the apocalyptic mood in a broader part of Israelite society. Some years ago I dared to say: what would have happened if someone had destroyed the Vatican a couple of centuries ago? Would there be a more open, democratic church, controlled and guided by laymen instead of priests? Exactly that was what happened in Jerusalem. The temple aristocracy did not vanish, but lost its power to define what Judaism is about.

It would be wrong now to argue that another movement, e.g. the Pharisees, would have taken the place of the priesthood, because reality is much more intricate. Still, there is one group out of many Jewish ones which has turned out to be the most successful over the centuries - the rabbinic movement, because it describes Israel as a learning community, and not a civilization focused on a piece of land and a temple.

1 I remind you of Jan Assmann's "Moses the Egyptian" and the discussion after that book. 


\section{The rabbinic movement}

The rabbinic movement can be described as "[...] a grand coalition of different groups and parties, held together by the belief that sectarian self-identification was a thing of the past"2. This grand coalition was both integrative and able to concentrate on one central issue - the Torah. It counteracted every other system. The rabbinic movement prevailed against assimilationist tendencies as well as apocalyptic and esoteric groups whose traces can indeed be found in rabbinic literature and beyond. ${ }^{3}$

Much has been written about the rabbinic movement and its social and religious basis ${ }^{4}$, therefore I can mention a few examples here to underpin my thesis that the rabbinic movement laid the foundations against a fundamentalist narrow mindedness in Judaism and the temptations of fundamentalism itself. I am narrowing it down to a small and limited territory, which is a violent struggle.

\section{The forgetful Joshua}

I begin with a poignant text from the Babylonian Talmud, bTemurah 16a:

Rav Judah reported in the name of Rav: When Moses departed [this world] for the Garden of Eden he said to Joshua: Ask me concerning all the doubts you have. He replied to him: My Master, have I ever left you for one hour and gone elsewhere? Did you not write concerning me in the Torah: But his servant Joshua the son of Nun departed not out of the tabernacle? Immediately the strength [of Moses] weakened and [Joshua] forgot three hundred laws and there arose [in his mind] seven hundred doubts [concerning laws]. Then all the Israelites rose up to kill him. The Holy One, blessed be He, then said to him [Joshua]: It is not possible to tell you. Go and occupy their attention in war [...]

What we learn here is that fighting or being a man of war is not even the second best thing to do in life, but a kind of punishment for not asking questions. The Rabbis are famous for their skepticism of war and military engagement. They invest some energy to prove that heroes from the past were more famous for struggling with words than for fighting.

Thus David, to mention only one important biblical figure, is depicted as scholar.

2 Cohen 1984, p. 50.

3 See e.g. the large amount of texts of the so-called Hekhalot-literature and of magical texts, cp. Schäfer (et al.) 1988.

4 See e.g. the works of Catherine Hezser. 


\section{The king of study - David attacks the Gibeonites}

The story of David's harp in Talmud Berakhot 3b-4a and Sanhedrin 16a is very famous. Every midnight the harp is driven by a soft north-wind and starts playing by itself, waking up the sleeping David to study Torah. Until dawn, he occupies himself with Torah and then receives the wise men of Israel to give them advice. Others say that he never slept, but studied Torah in the evening and composed the Psalms after midnight.

David is compared with Moses (Talmud Yoma 86b, Sota 9a, Avoda Zara 36b) deciding law cases in a line of tradition between Moses and Hillel and Shammai.

David expels the Gibeonites from Israel because they demanded revenge. The story is known. The Gibeonites, a group of people who once tricked Joshua into making a treaty with them, were later killed by Saul. King Saul broke the treaty that Joshua had signed and attacked the Gibeonites. Later still, during the time of King David, a famine occurred in Israel. When David asked the Lord about the famine, God said, "It is on account of Saul and his blood-stained house; it is because he put the Gibeonites to death" (2 Sam 21:1). To appease the Gibeonites and put an end to the famine, seven sons of Saul were given to them to be put to death (2 Sam 21:6). God healed Israel's land after that (2 Sam 21:14).

The Rabbis reflect on that story in Talmud Yevamot78b/79a. David accepts their plea for revenge but

David said: 'As to Saul, there have already elapsed the twelve months of the [first] year and it would be unusual to arrange for his mourning now. As to the nethinim, however, let them be summoned and we shall pacify them. Immediately the king called the Gibeonites, and said unto them "What shall I do for you? How shall I make atonement so that you will bless the Lord's inheritance? The Gibeonites answered him, We have no right to demand silver or gold from Saul or his family, nor do we have the right to put anyone [in Israel to death. What do you want me to do for you? David asked. They answered the king, As for the man who destroyed us and plotted against us so that we have been decimated and have no place anywhere in Israel,] let seven of his male descendants be given to us to be killed and their bodies exposed before the Lord [at Gibeah of Saul-the Lord's chosen one]' (2 Sam 21:3-6). He tried to pacify them (the Gibeonites) but they would not be pacified. Thereupon he said to them: This nation is distinguished by three characteristics: They (the Israelites) are merciful, bashful and benevolent. 'Merciful', for it is written, "[and none of the condemned things are to be found in your hands. Then the LORD will turn from his fierce anger,] will show you mercy, and will have compassion on you. He will increase your numbers, [as he promised on oath to your ancestors]' (Deut 13:17). 'Bashful', for it is written, 'So that the fear of God will be with you' (Exod 20:20). 'Benevolent', for it is written, '[For I have chosen him,] so that he will direct his children and his household [after him to keep the way of the LORD by doing what is right and just, so that the LORD will bring about for Abraham what he has promised him]' (Gen 18:19). Only he who cultivates these three characteristics is fit to join this nation. 'But the king took the two sons of Rizpah the daughter of Aiah, whom she bore into Saul, Armoni and 
Mephibosheth; and the five sons of Michal the daughter of Saul, whom she bore to Adriel the son of Barzillai the Meholathite.... And Rizpah the daughter of Aiah took sackcloth, and spread it for her upon the rock, from the beginning of harvest until water was poured upon them from heaven; and she suffered neither the birds of the air to rest on then by day, nor the beast of the field by night.'

According to the Rabbis, all extremism is harmful and should be avoided. A person should be calm and modest and devoted to the Torah, which offers not only a way to God but also a "portable homeland", to quote Heinrich Heine.

\section{The internal enemy}

The Rabbis define war and struggle much less as a fight against outer enemies than as an inner struggle against the evil inclination. ${ }^{5}$ Thus the internal enemy of man is the evil inclination, the yetzer ha-ra. The permanent struggle against this inner desire urging men to act in the wrong way can only be successful by means of the Torah. In the Avot the Rabbi Nathan A 23.6-7, fighting the evil inclination is compared to the defeat of a city full of mighty men, because mighty means mighty in the Torah, as it is written: "Praise the LORD, you his angels, you mighty ones who do his bidding, who obey his word" (Ps 103:20). Here the Rabbis compare people trained in the Torah - to be sure they mean themselves - as angels obeying the word of God.

The yetzer ha-ra is compared with an enemy that needs to be defeated. In Midrash Sifre Deuteronomy $§ 45$, it says:

'Therefore impress these My words upon your heart' (Deut 11:18) - this tells us that the words of Torah are like an elixir of life. This is comparable to a king who was angry with his son, struck him a violent blow, and placed a bandage on the wound. He told him: My son, as long as this bandage remains on your wound, you may eat whatever you please and drink whatever you please, and bathe either in hot or cold water, and you will come to no harm. But if you remove it, it will immediately fester. Thus the Holy One, blessed be He, said to Israel: I created your evil yetzer, and there is nothing more evil than it, [but] 'if you do right, there is uplift' (Gen 4:7) - Be occupied with words of Torah and it will not reign over you. But if you abandon words of Torah, then it will gain mastery over you, as it is said (ibid.): 'sin crouches at the door, its urge is toward you' - it has no business other than with you. But if you wish, you can rule over it, as it is said (ibid.): 'yet you can be its master: If your enemy is hungry, give him bread to eat $[. .$.$] you will be heaping live coals on his$ head [...]' (Prov 25:21). The evil yetzer is evil, the one who created it [himself] testifies that it is evil, as it is said: 'since the yetzer of man's heart is evil from his youth' (Gen 8:21) (Translation Rosen Zvi, Demonic Desires, p. 21).

$5 \quad$ See Rosen Zvi 2011. 
This excerpt is written in quite radical language, it is not only talking about the enemy, but is also mentioning the parable about the injury the father is inflicting on his son, without any obvious reason. "Fight" and "victory" are very important terms here that express the inner turmoil of man.

\section{The external enemy}

Let me come to another issue. The Rabbis are talking about the enemies of Israel; they are depicting many scenarios where the so-called reshaim - the wicked evildoers - are mentioned. They speak about the end of villains, such as Titus, who is tortured by a mosquito which flies into his brain after the siege of Jerusalem (see Talmud Gittin 56b). One of the total enemies of Israel is Amaleq, whose deeds shall never be forgotten. According to the rabbinic view on history, bad behavior will leave its marks on the next generation. But it is remarkable that the Rabbis do not speak of a revenge or vengeance conducted by human beings - and of course not by Rabbis - but through the just God, who will once - and hopefully in the near future - rescue Israel from its enemies.

Ishmael and much more Esau, who becomes the symbol of the treacherous Rome and later the Christian empire, will be punished in the future. In the meantime, Israel has to come to terms with them. ${ }^{6}$

Martial law, as it is introduced in the Bible, is often commented on by the Rabbis. The role of the king, i.e. the political leader, is restricted radically in the so-called voluntary war (milchemet ha-reshut, as opposed to imposed defensive warfare). It reflects a sceptical attitude towards political authorities, based on both experience and the religious-cultural perception of a "theocracy". Actually, the world and the land belong to God; His volition, expressed by the Torah through Moses, is of paramount importance for a life agreeable to Him. This also applies to the war and its ultimate aim, to make way for a life in freedom, according to the Torah and to protect the land, given by God, from idolatry.

The biblical text Deut 20 plays an important part here, where a priest has to encourage the fighters before the battle. The general has to send some of the men back home, either because they have just married, built a new home, planted a vineyard or simply because they are too scared.

This central text was commented on according to the tradition and was interpreted generously (i.a. Mishnah and Tosefta Sota 8/7; Sifre Deuteronomy $\S 191-204)$

To take a single example, (re)building, buying or inheriting a house, as well as receiving one as a gift, also count as reasons to stay away from service. Besides, indepth discussions about biblical wars, wars during the seizure etc. stay on a very

6 See Langer 2009. 
theoretical level and do not cover real situations. It is obvious that the Rabbis avoid any military discussion. ${ }^{7}$

Moses Maimonides eventually offers an in-depth description in his important work Mishne Torah. ${ }^{8}$

The external enemy can also be fought by means of mockery, polemics or even humor. Besides the controversial question of whether humor should be used as a weapon of the weak against the strong, Jewish tradition knows to use both outward and inward criticism (self-criticism).

\section{The case study of Amalek}

Good and bad characters in the Bible are lasting bearers of memories and allow constant updated refilling. Esau-Edom stands for Rome and Christianity, while Jacob obviously stands for Israel.

The story of Esther - a rescue out of the deepest threat in the diaspora - is constantly adapted and leads to the Purim games.

Like a never-ending circle of cause and effect, history is intermeshed from the old times until today. This shows the biblical Book of Esther, embellished in the tradition: King Saul from the tribe of Benjamin once spared Agag, King of the Amalekites (1 Sam 15), ancestor of Haman, who threatened Israel with Genocide according to the Book of Esther. David, the Judean, spared Shimi ben Gera (2 Sam 16), also from the tribe of Benjamin, who had cursed him. Thus Mordecai, his descendant, can arise, the uncle of Esther, who had a large share in rescuing the Jews from the hands of Haman, the villain. Haman himself descends from Amalek, the grandson of Esau. In Judaism, Amalek is a symbol of both remembrance and oblivion. In Deut 25:17-19 it says:

${ }^{17}$ Remember what the Amalekites did to you along the way when you came out of Egypt. ${ }^{18}$ When you were weary and worn out, they met you on your journey and attacked all who were lagging behind; they had no fear of God. ${ }^{19}$ When the Lord your God gives you rest from all the enemies around you in the land he is giving you to possess as an inheritance, you shall blot out the name of Amalek from under heaven. Do not forget!

The basic hostility is based on the exodus out of Egypt. The pursuit of innocent stragglers, the assault of the weakest, is a symbol of wrong behavior. Over the centuries, Amalek became a role model for the ultimate evil, the ruthless attacker, the wrecker.

7 See Maier 2008; Stemberger 2005.

8 See Maier 2008. 
Repeatedly, Amalek is loaded, identified, symbolically blurred or generalized. Only at the end of days, together with the coming of the Messiah, will Amalek be utterly defeated. This means that Israel has no choice but to live with evil.

Saul had missed the opportunity to destroy Amalek and the threat once and for all. Amalek survived as a historical phenomenon.

Thus, every single generation is requested to delete memories but at the same time, not to forget. This may sound like a paradox, but on closer examination it is not. Let me give you an example. When I went to school, history teachers avoided teaching about the time of National Socialism. This, in fact, is the opposite of deleting memories, it is concealment and repression. Remembering Amalek means nothing but remembering its crimes; forgetting means blotting out its veneration, its demonization, its almost religious exaltation. Remembrance and commemoration have to make oblivion possible, reconciliation with one's own history, not with history itself. Amalek itself remains the evil principle everyone has to be prepared for at all times. Amalek must not disappear from strategic thinking, but from hearts. The crime must be kept in mind by all generations. The villain, though, isn't worth remembering and should fall into oblivion.

Jewish tradition offers another solution to this apparent aporia of remembrance and oblivion. The Babylonian Talmud (Gittin 57b and Sanhedrin 96b) tells of Haman's grandchildren, Amalek's descendants in the Book of Esther, allegedly teaching the Torah in Bnei Brak. Thus, Amalek can be forgotten by changing his name, his true identity of evil, for the better. Amalek disappeared when his descendants became Jewish scholars; he turned into a different, new, promising identity as a part of Israel. In this way, it became possible for the descendants of villains to keep the memories of the crimes alive, but forget Amalek himself.

A radical break with a pre-history and the entering into a new identity is possible at all times, if this happens by honest conviction.

The task of a commemorative culture is clearly outlined. It preserves memory in a positive sense as well as the memory of various negative events, stances and ideologies. It pleads also for oblivion in a sense of a conscious and specific demystification of the fascination of the negative.

The ancient Hebrew formula "yimach shmo (we zikhro)", which means "may his name (and his memory) be deleted" is often added when villains are mentioned by their names. The mention of evil is connected to the intention of not giving him a memory. Deleting the name means deleting his existence. The crime cannot be reversed, but the villains can be banned from memory.

Remembrance and memory are not only connected to dark times and periods, but also to numerous positive experiences, events and achievements.

Commemorative culture reminds us of the many big and small steps in history and of the people to whom we owe them. Jewish tradition talks about the new whilst appreciating the tradition; it demands innovation and preservation of memory, and falls back on known role models to describe the new. In a famous section of the Talmud (bMenachot 29b), Moses listens to the interpretation of 
Rabbi Aqiva, a famous scholar in the $2^{\text {nd }}$ century at the heavenly Academy, after his death. This is new to him, even though Aqiva is only reproducing the message of Moses. Despite the biblical word of Kohelet, that "there is nothing new under the sun", every generation still needs to create something new, by interpreting what is already in existence anew and displaying it in an innovative manner.

New experiences are based on existing scholarliness. Not everything can or has to be preserved; here also Jewish traditions contribute their insights. A great deal got lost, was forgotten or seems to be outdated. One or another approach can even be scrapped, rejected or at least can be appreciated as valid for ancient times even if it is not up-to-date anymore. That is also commemorative culture. At the time of the Jerusalem temple, everything evolved around it, its cult and its sacrifices. After it had been destroyed, it was not that hard to compensate the loss by creating new central models of identification, especially the occupation with the Torah, conveyed by scholars. The temple was etched into the collective memory, its remembrance replaced the real sacrifice and new sites of liturgy and prayer, such as the synagogue and the Beit Midrash, became centers for the community and a place develop and pass on Jewish tradition. Holidays and festivities developed and were adapted in confrontation with Christianity and Islam. Sometimes it is not sufficient to adapt known things, and then it becomes necessary to create new holidays and festivities, new reminders and ways of remembrance, e.g. Hanukkah or the Yom ha Shoah (the day of remembrance of the victims of the Shoah and the resistance).

\section{The rabbinic world of teaching and learning}

The world of the Rabbis is the world of the text, the history is the history sketched out by the Bible, the law is the halacha of a-somehow - utopian society where the Rabbis - in reality a small group of scholars - construct a perfect society, reconstruct the past and sketch the future world to come.

The Rabbis reconstruct the past after their own hearts and imagine the future in accordance with their own ideas. Only here and now is the attempt to get as close as possible to reality and to shape it by rabbinic visions perceptible.

If we accept that the Rabbis have never intended to fight with arms against external or internal enemies, we have to state that they do their best to gain control over important parts of Jewish society. They try to define the role of man and woman, try to influence jurisprudence, social welfare, try to answer the questions about God, angels and demons and about the right or wrong cultic devotion, prayers and services. They struggle with other groups like priests or Hellenistic thinkers, but they are successful, not by means of power, but through their belief of integration, compromise and discussion. But most of all, they try to establish a system of teaching and learning. Their struggle mainly takes place within the protective atmosphere of the Beit Midrash, in a surrounding that is a 
small world of its own. Learning and teaching the Torah becomes a way of life pleasing to God, a lifelong task, an end in itself. That does not mean that one should not interact in a life outside the School - a vocational education is desirable - but the School remains the actual social center. There the exegesis and new interpretation of the Torah takes place, and this is where the rabbinic ideal world is constructed, in the close contact of teachers with their students. The teacher becomes an intermediary between God and the world by interpreting the text and God's will. That means a claim to power and a lot of responsibility. Thus, strict rules of conduct are another important part of the study of the Torah and inseparably connected to it.

The Rabbis themselves do not draw a solely idealized image of the School. Funnily enough, they sometimes seem to laugh about themselves telling stories of all and sundry.

And here I give an example of how the Rabbis could sometimes act. In Talmud Bava Batra 75a we read:

'Your gates of sparkling jewels' (Isa 54:12) [is to be understood] as R. Johanan [explained] when he [once] sat and gave an exposition: The Holy One, blessed be He, will in time to come bring precious stones and pearls which are thirty [cubits] by thirty and will cut out from them [openings] ten [cubits] by twenty, and will set them up in the gates of Jerusalem. A certain student sneered at him: [Jewels] of the size of a dove's egg are not to be found; are [jewels] of such a size to be found? After a time, his ship sailed out to sea [where] he saw ministering angels engaged in cutting precious stones and pearls which were thirty [cubits] by thirty and on which were engravings of ten [cubits] by twenty. He said unto them: For whom are these? They replied that the Holy One, blessed be He, would in time to come set them up in the gates of Jerusalem. [When] he came [again] before R. Johanan he said unto him: Expound, O my master; it is becoming for you to expound; as you said, so have I seen. He replied unto him: Raca (Fool), had you not seen, would not you have believed? You are [then] sneering at the words of the Sages! He set his eyes on him and [the student] turned into a heap of bones.

The approach to the students is extremely harsh. This text shows that the reality conveyed in the (biblical) text does not need an external confirmation (conception, observation of nature, profane science). Whoever doubts the "reality" described by the Bible is deemed unfit in the eyes of the Rabbis.

This narrative is one of many texts in a group which is embedded in the context of teaching, and where debates end with the death of one of the participants. Talmud Hagiga $3 b^{9}$ describes the power of the teacher in a legendary way. R. Eliezer took out the eyes of Jose b. Durmasqit's, his student, because the latter had sold him a decision of the School as a novelty, while it had actually been an old tradition known to Eliezer. After he had calmed down, he put his student's eyes back into their sockets.

9 See Rubenstein 2010, pp. 91-115. With further literature. 
Removing the student's eyes stands for the blindness of the School concerning the old tradition, and returning his eyes acts as an "eye-opener". The teachers themselves give each other tit for tat, when R. Kahana once burdened R. Johanan with difficult material and thereby shamed him, he died on the spot (see bBava Qamma 117ab).

This shows that those debates didn't only occur in the hierarchical relationship between students and their teachers, but also amongst colleagues, and could sometimes end lethally. Rabbinic tradition gives many examples for differences of opinion, in Talmud Pesachim 113b it is written that "dogs, fowl, Persian priests, prostitutes - and 'scholars in Babylonia' hate each other!".

On the other hand, it is a part of rabbinic ideology to allow different opinions and differences of opinion about a certain subject. These differences have been documented consciously. The world of the Rabbis is the world of the text, which is never fully understood, but always a task to be interpreted. In the postmodern world rabbinic exegesis was read in the light of Foucault, Bakhtin, Kristeva or Barthes, but this reading is single-edged and misleading. Discussing the true meaning is not the same as "anything goes". Not every meaning is true, not every opinion is reported, and there is much more compliance than sometimes expected. Nobody in rabbinic society will doubt that the Torah is an intermediary to God. No one will doubt that the fathers and mothers of Judaism play an eminent role in developing Jewish identity; no one will doubt that Israel has a special task in the world. No one will doubt that there is a difference between us and them, between Israel and the nations, between men and women, between right and wrong behavior. No one will doubt that Jesus will burn in hell and Israel - I mean most of it - has a ticket for the world to come.

The Rabbis used to ban and exclude people, and in later times they struggled by means of harsh polemics not only with Christians, but to be sure with the Karaites, who entirely question the rabbinic construction of a necessary tradition of interpretation of the Torah. For the Rabbis the Torah was sanctioned by God himself, who spoke with Moses on Mount Sinai from face to face and instructed him with each and every halachic rule which will ever be uttered in the house of study thousands of years after the exodus. ${ }^{10}$

So - no doubt - rabbinic world-view is not devoid of ideology, does not wish to control Jewish society and is not free of polemics and a feeling for borders. But there is a difference in speaking of a one and only deciding messianic figure such as Jesus, or even the teacher of righteousness in Qumran, or of a local scholar in Tiberias or Machoza.

But what made the Rabbis so important as a paradigm against fundamentalism was their strong attempt to discuss the fundamentalist approach and to have the truth, may it come directly from God via a sacred text, or may it be intermediated by a human being - skepticism is in some aspect a Jewish habit. A text like the

10 The so-called Law given to Moses at Sinai (Hebrew Halachah le-Moshe mi-Sinai). 
medieval Alphabet of Ben Sira, a bitter satire against the Rabbis, is only one example for this critical mind.

Moses Maimonides' 13 principles of faith ${ }^{11}$ were an attempt to define the "true Judaism", but have never gained dogmatic value. They were and are used in liturgy, not as principles of faith. This is very important in order to understand the rabbinic attempt to keep discussion open.

The most important text of the rabbinic era was and is the Babylonian Talmud. It developed in the context of a relatively liberal Sassanian Persian empire. The famous utterance of Rabbi Shmuel is typical for the co-existence with the Persian Empire: "dina de malkhuta dina" = the law of the empire is the law (bBava Qama 113a), which means nothing less than the Rabbis accept the authority of the state.

The Rabbis accept the Persian Empire also as a state, where Jews can live in a kind of homeland. ${ }^{12}$ Some texts make clear that nobody should urge the Messiah, no mass immigration to Israel is allowed and - to be sure - only the Messiah will lead the masses to Israel. In the meantime, living in the new homeland in the Mesopotamic home from where Abraham once came, enables Jews to learn and teach in the best academies of the Antiquity.

Diasporic existence is the normal case, Jews are a minority in a world dominated by Muslims, and, unfortunately, by Christians. Jews flex their muscles by talking about the time when the Messiah is arriving ${ }^{13}$, but in the meantime try to come to terms with the majority. May God build up the Temple tomorrow, but a day in God's measure lasts 1000 years.

But then, after 1000 years of "Next year in Jerusalem" the dream came true. A minority culture turned into a majority Jewish state. One can read texts from the Middle Ages about the vengeance of God at the end of the days which have become eerily present. Letting the Messiah kill all enemies in a narrative of hope for rescue and help is not the same as killing enemies of a real existing state.

Suddenly, ancient martial laws are brought back to a political reality, references to the glorious times of the biblical kings and the Maccabeans are made. The Realpolitik of a Jewish state shifts the messianic perspective and creates new challenges for a religious community, split into different movements, which has to face this new state.

11 In his commentary on Mishnah Sanhedrin 10. In English translation here: http:// www.mesora.org/13principles.html [26.04.2016].

12 See e.g. bKetubbot 110b-111a.

13 See Maimonides' thoughts on the Messiah, war, the Sanhedrin, the judges etc., see Albertini 2009. 


\section{Conclusion}

Muslims and Christians have had the platform of history to prove that Allah with his prophet Mohammed or Jesus are surely right, and if one does not believe he will be "convinced" with power.

Jews might have written sometimes about the power of vengeance, of the wild rose under thorns, Israel, which alone has the truth; about a history confirmed in the stars, that Israel is God's eyeball. But being a minority in the diaspora or even in Israel demands other means of survival in actual reality. Being a more or (much) less tolerated minority gave Jews the chance to stay open for a lot of different influences, making them the perfect "luftmenschen"; dreamers in a world dominated by others. The encounter with the others was not an encounter with the immigrant or refugee but with the dominant cultures. Jews are accustomed to having the truth as long as nobody wants the proof. But in the end God will prove it.

Judaism as a religious phenomenon in Israel, where Jews are dominating, makes everything different.

That concludes my contribution and I would like to refer to the article by Yaakov Ariel in this journal.

\section{References}

Albertini, Francesca: Die Konzeption des Messias bei Maimonides und die frühmittelalterliche islamische Philosophie (Studia Judaica 44). Berlin / New York 2009.

Assmann, Jan: Moses the Egyptian. The Memory of Egypt in Western Monotheism. Cambridge, Mass. 1997.

Cohen, Shaye J.D.: "The Significance of Yavneh: Pharisees, Rabbis, and the End of Jewish Sectarianism", in: HUCA (55) 1984, pp. 27-53.

Elßner, Thomas R.: Josua und seine Kriege in jüdischer und christlicher Rezeptionsgeschichte (Reihe Theologie und Frieden 37). Stuttgart 2008.

Hezser, Catherine (ed.): The Oxford Handbook of Jewish Daily Life in Roman Palestine. Oxford 2010.

Hezser, Catherine: Jewish Literacy in Roman Palestine (TSAJ 81). Tübingen 2001.

Hezser, Catherine: The Social Structure of the Rabbinic Movement in Roman Palestine (TSAJ 66). Tübingen 1997.

Langer, Gerhard: Menschen-Bildung. Rabbinisches zu Lernen und Lehren jenseits von Pisa. Wien et al. 2012.

Langer, Gerhard (ed.): Esau - Bruder und Feind. Göttingen 2009.

Maier, Johann: “Aus der Sicht des Judentums: Der Krieg”, 2008, available at: http://www. david.juden.at/2008/78/9_maier.htm [26.04.2016].

Rosen-Zvi, Ishay: Demonic Desires. "Yetzer Hara" and the Problem of Evil in Late Antiquity. Philadelphia 2011.

Rubenstein, Jeffrey L.: Stories of the Babylonian Talmud. Baltimore 2010. 
Stemberger, Günter: "La guerra nella Mišnah e nei Midrašim halakici”, in: Perani, Mauro (ed.): Guerra santa, guerra e pace dal Vicino Oriente Antico alle tradizioni ebraica, cristiana e islamica (AISG Testi e studi 14). Florenz 2005, pp.131-139.

Schäfer, Peter: Hekhalotstudien (TStAJ 19). Tübingen 1988.

Schäfer, Peter et al. (eds.): Magische Texte aus der Kairoer Geniza (TStAJ 42/64). 2 vol. Tübingen 1994/1997. 